\title{
GOVERNANCE DEVELOPMENT OF PUJON KIDUL'S VILLAGE TOURISM
}

\author{
Natcha Longkul ${ }^{1}$, Wanwisa Wongpon ${ }^{2}$, Wipawee Burana ${ }^{3}$ \\ Dara Fitria Melani Putri ${ }^{4}$, Alliya Safitri ${ }^{5}$, Ach. Apriyanto Romadhon ${ }^{6}$ \\ ${ }^{1,2,3}$ Department of Public Administration (Fiscal Management), College of Local \\ Administration, Khon Kaen University, Thailand \\ ${ }^{4,5,6}$ Department of Government Science, Faculty of Social and Political Science, \\ University of Muhammadiyah Malang, Indonesia \\ Email: 1Natcha_L@kkumail.com., \\ Email: ${ }^{2}$ wanwisa_w@kkumail.com, \\ Email: ${ }^{3}$ wepawee_B@kkumail.com., \\ Email: ${ }^{4}$ dara@gmail.com., \\ Email: 5alliya@gmail.com., \\ Email: ${ }^{6}$ apriyanto@g mail.com
}

\begin{abstract}
This research is a qualitative research study. This research aims to 1) study essential factors in the development of the tourist village of Pujon Kidul 2) study sought to answer how Pujon Kidul drives the development of a tourism village. Data were collected using in-depth interviews, discussions from crucial informants such as the head of Pujon Kidul village, and non-participatory interviews. The study results show that the Pujon Kidul tourism village's governance has four essential factors for development. 1) Human Capital, most people in the village receive working skills training resulting from nearby villages' cooperation to have skills in the problems encountered because the village people have an education at the elementary level. Therefore is an obstacle to development 2) Local Participation is led by the head of the village, which is the primary determinant and determination the village people cooperate with and follow the leader. 3) Financial Management The village's development budget is mainly from the village's capitalization, beginning with the head of the village. 4) Managerial Skill, the head of the village, has used strategic management to manage village development, including developing its agricultural and resources to increase value. Governance of Pujon Kidul tourism village development the most encouraging factors are local participation and managerial skills; both factors are ready for development. People in the village are active and involved in development. Including the leader's ability to create a point of sale for the community, planning, decisions, and adding value to community resources as for the other two factors is still a management difficulty in human capital. People still lack access to primary education, a necessary foundation that local governments should emphasize and attend. Financial management factors lack government support, which is considered as the main factor in development.
\end{abstract}

Keywords: Financial Management, Governance, Human Capital, Local Participation Managerial skills ., Tourism Village, 


\section{Introduction}

Indonesia's tourism development tends to be fair, considering Indonesia's natural conditions and beautiful landscapes and still maintains its natural tourism identity. Each region has the potential of local tourism in the form of nature tourism and cultural tourism. Moreover, one of Indonesia's tourism development is Tourism Village. At present, Tourism Village is proliferating. Many villages have developed into tourist villages. Furthermore, in the future, Indonesia has set a target number of villages to be developed into tourist villages in large numbers.

Pujon Kidul tourism village is one of the villages that have been approved since 2014 and is involved with various stakeholders in the development of rural tourism using excellent outdoor activities. This tourism village is located in Pujon Kidul village, Pujon Sub-district, Malang Regency, East Java Province. This tourism village has many tour packages such as coffee plantations, trekking, horseback riding, mountain tracking, agriculture, and livestock education. As the country's best agricultural tourism village, the Tourism Minister received the Pokdarwis Mandiri Award for the Ruru group, the Dragon Pujon Kidul tourism group.

Development of village tourism or tour village is also considered to have the ability to minimize the potential urbanization of society from rural to urban areas because it can create economic activity in rural areas based on tourism activities (tourism economy). The productive potential of local potentials, including those of rural potentials, can be encouraged to grow and develop by utilizing village-owned resources to be an effective instrument in fostering the sociocultural and economic development of rural communities. Furthermore, various efforts will be encouraged to preserve and empower the potential of unique local culture and local wisdom values that are likely to be threatened with extinction due to the intensified globalization and rural entry into the countryside. Village tourism is based on the village's potential utilization with all the community entities, nature, and culture in it as the power of tourist attraction. ${ }^{1}$

Over the past decade, rural tourism and tour villages' development has been running so rapidly and spreading in almost all Indonesia provinces. Moreover, with the encouragement of PNPM (Mandiri Tourism Community Empowerment Program), many new tourist villages have sprung up in various regions. They try to capture the opportunities for tourism development and market interest to seek alternative tourism destinations outside popular destinations that are well known in mass tourism and conventional tourism.

Many things must influence the development of a prosperous tourism village. The role of government is an integral part of tourism about political policies and

1 Karim, A. (2008). Capitalists Pariwisata dan Marginalisasi Masyarakat Lokal di Lombok.Yogyakarta: Genta Press. 
philosophies. Regardless of the type of organization or the government role's level of responsibility, the central government or the local government must agree with it. Overall strategy Government agencies will play an essential role in the development of tourism resources. Planning for appropriate policy allocation and providing consultation on strategies, offering opportunities for consultation and collaborating with the private sector, and preparing destination marketing strategies based on the appropriate market their needs and desires are significant factors in developing tourist destinations. ${ }^{2}$ Including encourages community participation, appropriate management, including the development of tourism infrastructure. The study of these factors is an essential factor that supports rural tourism development. However, it is only part of the development. Therefore, tourism in rural areas needs to consider all factors that contribute to development. This research aims to study the development of government regulation on the Pujon Kidul tourism village and study essential factors in the development of the tourist village of Pujon Kidul. In particular, the study sought to answer how Pujon Kidul drivers the development of a tourist village.

\section{Theoretical Framework}

Tourism Village or the "Desa Wisata" concept that the Indonesian government began in the expectation that the village can be a player in the tourism industry. This concept has a lot of the same stroke with the concept of Community Based Tourism. By adopting the two concepts, many Indonesian villages goal could be a player in the tourism industry. ${ }^{3}$

The Ministry of Tourism in Indonesia has a target in the tourism sector in 2019 to bring in 20 million foreign tourists and 275 million domestic tourists. ${ }^{4}$ The development of villages into tourist attractions is one way to increase tourism destinations in Indonesia.

Development is a process that creates growth, progress, positive change, or physical, economic, environmental, social, and demographic components. The goal of development is to increase the population's level and quality of life and the creation or expansion of local jobs and income opportunities regionally, without destroying the environmental resources. Develop is a visible and useful development, not necessarily immediately, including aspects of quality changes and the creation of conditions to continue the changes. ${ }^{5}$

2 Essays, UK. (, 2018). Role of Government in Tourism. Retrieved 15 February 2020, from https://www.ukessays. com/essays/tourism/role-of-government-in-tourism-tourism-essay.php

3 Komunitas Averroes, 2017. Pujon Kidul Tourism Village. Retrieved 6 January 2020, from https: / /www.kompasiana. $\mathrm{com} /$ avecom/5a0bb20d2599ec04e617da73/kisah-di-balik-suksesnya-desa-wisata-pujon-kidul?page=all

4 Siti Nurul Wahida, Yana Syafrieyana, Oman Sukmana. 2020. Collaboration with Pantehelix Model in Developing Kajoetangan heritage Tourism in Malang. Vol.03 No.01. Journal of Local Government Issues. http://ejournal. umm.ac.id/index.php/LOGOS/index

5 Sid Israel, 2018. Development. Retrieved 7 January 2020, from https://www.sid-israel.org/en/DevelopmentIssues/What-is-Development. 
Rural areas are identical to poverty and underdevelopment, especially in Indonesia. However, the village also has resources that can be developed as a tourist village from these factors. The development of this tourism village is supported by the Village Law, which is given the authority to empower the community and advance it. ${ }^{6}$

Governance is generally defined as the use of power or authority by political leaders for their citizens or subjects' welfare. It is a complex process in which some sectors of society wield power and uphold and disseminate public policy that directly affects human and institutional and economic and social development. Strength is done by participating sector communities always for the common good because it is essential to demand citizens and the state's respect and cooperation. Thus, many of the government is the proper and effective utilization of resources. ${ }^{7}$

\section{Community-Based Tourism}

(CBT) is a tool to strengthen local organizations to manage natural and cultural resources through the participation of people in the community, allowing communities to participate in the direction of development and benefits from tourism. ${ }^{8}$

Four factors influence the development of tourism village governance Pujon Kidul namely:

\section{a. Human Capital}

Human Capital has an economic definition that the skills and knowledge that a person has to create potential production focus on Studies that affect productivity and labor efficiency by developing capabilities Within the person and the investment in human development. However, in the 21 st-century world, the definition of human capital should not be limited to just in the context of economics. It defined human capital as a involves knowledge, skills, abilities, personality, emotions and maturity, experience, relationships, and education. It described that training and education are essential to Human capital development.

The inclusion of human capital in growth accounting treats increases in education as enhancing the productivity of individuals. Differential productivity is measured by how much high earnings are for workers of different levels of education. That is, earnings ratios by education (e.g., college/ high school graduates) are held constant, and the fractions of workers with different levels of education are allowed to change from one year to the next. These relative "prices" can be updated in the same way that prices change in chain-weighted commodities. ${ }^{9}$

\section{b. Local Participation}

The form of tourism through the participation process of people in the

6 Ali Roziqin, Adejaya MS, Khadir Ali. (2019). Strengthening Local Economy through Tourism Village: Case Study in Dukuh Dalem, Sleman City. PROCEEDINGS: IAPAAnnual Conference, 2018.

7 Tamayaocsu. (2014). What is governance? Retrieved 7 January 2020, from https://tamayaosbc.wordpress. com/2014/08/21/what-is-governance/

8 CBT Youth Club. (n.d.). Community - Based Tourism, from https://cbtyouth.wordpress.com/cbt-youth/cbt/

9 Becker, G. S. (1962). Investment in human capital: A theoretical analysis. Journal of Political Economy, 70, 9- 49. 
community provides opportunities for the community to participate in determining the direction of development and benefit from tourism. It is a method that focuses on local society (both directly and indirectly) and indirect participation in the tourism industry to provide opportunities to access, manage, and develop tourism, which affects political integrity. Through a democratic life, including sharing the fair profits of tourism activities to return to the local. ${ }^{10}$

\section{c. Financial Management}

Financial management for business organizations means the management of the acquisition and use of funds. Business activities are all related to the capital change to create the business's highest value in the financial dimension.

It may be the acquisition or use of funds such as building a factory, buying new machinery, Borrowing money from banks, increasing capital, etc. Each day, executives are always involved in financial decisions in 3 significant areas: Capital Investment, Capital Structure, and Working Capital Management. ${ }^{11}$

\section{d. Managerial Skills}

Executives regardless of the level or in which organization? It has four management functions for planning, organization, orientation, and control. In which the management can successfully perform administrative duties. Must have good management skills. The necessary skills that should be owned by an executive are technical, human skills, and conceptual skills.

1. Technical skills are the ability to apply knowledge and expertise in workrelated for senior management. This skill will be about general knowledge of the organization. Moreover, middle and beginning managers, will be the specific skills and abilities in the work performed, such as finance, human resources, information technology, computer systems, marketing, laws, etc.

2. Social skills are the skills to create coordination among the groups that the executives are responsible for. Moreover, it is a work that involves the attitude, communication, and interests of individuals and groups. Additionally, it is a skill to work with people.

3. Conceptual skills are the ability to look at the organization as a whole executive with cognitive skills. It will be able to understand the relationships of various departments in the organization that affect each other and understand the relationship between the organization and organizational environment, including how one part of the organization will affect other parts. ${ }^{12}$

10 Garrod, Brain. (, 2001). Local Participation in the Planning and Management of Eco-tourism: A Revised Model Approach Bristol. England: the University of the West of England.

11 Krisda Sektrakul. (2019). หลักการบริหารการเงินฉบับย่อสาหรับการลงทุนในบริษัทจดทะเบียน. Retrieved 13 January 2020, from https://www.set.or.th/set/financialplanning/knowledgedetail.do?contentId=576\&type=article

12 Sdcenter. (2011). Good managerial skills. Retrieved 13 January 2020, from http://oknation.nationtv.tv/blog/ thaidmag/2011/06/30/entry-1 


\section{Literature Review}

The research studied essential factors in the development of tourism village 1.Human Capital 2.Local Participation, 3.Financial Management, and 4.Managerial skills. The researcher has compiled related research as follows:

Community-Based Tourism: A case study of Baan Rong Fong, Rong Fong SubDistrict, Mueang Phrae District, Phrae Province conducted by Chutikan Kantha-oo (2017) The purpose of the research is to study the potential of the Baan Rong Fong community. The study found that tourism management was planned by local participation, including community leaders, local agencies, and community members. ${ }^{13}$

Enable Factors in Community Development Achievement Based on the Sufficiency Economy Philosophy of Ban Namsab Community, Wangnamkheo Sub-district, Wangnamkheo District, Nakhonratchasima Province conducted by Anucha pimindnok, Pakkawan lunsomgrong. (2015) The purpose of the research is to study the factors that affect community development success. The study found that Factors contributing to the success of community development include external factors such as support from the government to provide training. Budget support Procurement of markets to support community products, support, and cooperation from factors within the community such as Funding contributions, funding to be used in carrying out community development activities, Exchange of experiences, creating networking among people in the community for activities and career development. In which both factors are positively correlated with success. ${ }^{14}$

PENINGKATAN

KAPASITAS

PENGELOLAAN DESA WISATA KAFE SAWAH PUJON KIDUL conducted by Erlin, Aang and Andi, (2019) The purpose of the research is to improve the quality of human resources and increase the capacity of Kafe Sawah as a tourist destination. From the study, it was found the employee improve their language skills and are more confident in communicating with foreigners. ${ }^{15}$

\section{Research Methods}

The study examined the development of the management of the tourist village of Pujon Kidul. Pujon Kidul is one of the most successful tourist villages capable of generating income and stimulating Indonesia's economy in the East Java region

This study's main objective is to study essential factors in the development of the

13 Chutikan Kantha-oo. (2017). COMMUNITY-BASED TOURISM: A CASE STUDY OF BAAN RONG FONG, RONG FONG SUB-DISTRICT, MUEANG PHRAE DISTRICT, PHRAE PROVINCE. The Degree of Master of Arts Program in Human and Social Development (interdisciplinary Program) Graduate School. Chulalongkorn University.

14 Anucha pimindnok, Pakkawan lunsomgrong. (2015). Enable Factors in Community Development Achievement Based on the Sufficiency Economy Philosophy of Ban Namsab Community, Wangnamkheo Sub-district, Wangnamkheo District, Nakhonratchasima Province. Nakhonratchasima: Nakhonratchasima College.

15 Erlin Melani, Aang Afandi, Andi Kusuma Indrawan. (2019). Peningkatan Kapasitas Pengelolaan Desa Wisata Kafe Saw ah Pujon Kidul. Jurnal PKM: Pengabdian kepada Masyarakat. 
tourist village of Pujon Kidul. In particular, the study sought to answer how Pujon Kidul drives the development of a tourist village.

This study uses qualitative research adjusting on document research and fieldwork through purposive sampling, as for Chai Photisita (2007) ${ }^{16}$ The researcher chose a sample that can provide the most useful data for the study, which are called key informants that can provide the most useful data. In this study, qualitative research is a process to inquire about development, governance, and essential factors in the development of Pujon Kidul Village to be a tourism village, from beginning to the present. Data were collected using in-depth interviews, and interviews were conducted based on the open-ended interview guide from the head of Pujon Kidul village to collect primary data.

For secondary data analysis, theoretical analysis is used as the basis for classifying events and analyzing documents from relevant studies to find out the results of studies that are consistent or contradict other studies.

\section{Results and Discussion \\ History of Pujon Kidul Village}

Pujon Kidul is a tourism village located in the Pujon district in Malang Regency, East Java. With a population of 4,473 people from 3 villages, namely Krajan, Maron, and Tulungrejo, the concept of a tourism village is Pujon Kidul. Udi Hartoko is the head of the village in Pujon Kidul. Since 2011, he has wanted to change the village, beginning with the effort to repair clean water management in the village using a tourism village concept. Udi said that at first, there were not many people interested in this idea. However, he still pushes on after his efforts. The villagers started to respond positively by using their resources to attract the Pujon Kidul. Famous for its coffee shops with hilly views, the weather in this village is cold. Along with the beautiful lush rice fields attract 3,000 people on weekends and 500 people on weekdays. Besides working at a coffee shop, the villagers also make a living by raising dairy cows such as fresh milk, milk candies, cheese, processed milk planting, herbs and harvesting fruits such as passion fruit, apples, and guava.

Since becoming a tourist village, Pujon Kidul's income has risen to 80 million rupiahs (the US $\$ 6$,022) in 2016, the highest in 377 villages in the Malang area. With many creative efforts this village has produced, Pujon Kidul Received the Climate Village (Proklim) award from the Ministry of Environment and Forestry in December 2016 .

However, there are some problems that the tourism village still faces. The problem is the lack of human resources in the village and limited knowledge and education. The average population of

16 Chai Phositita. (2007). Art and science of qualitative research. Nakornpathom: Institute for population and social research Mahidol university. 
primary school education also includes land issues such as a shortage of land to build a landmark to support tourism potential.

The researcher has analyzed Pujon Kidul Village Development.

\section{How does Pujon Kidul manage governance the development of village tourism?}

From the concept of Pujon Kidul village development becomes a tourism village and adds value to existing farmers by using the potential of existing agricultural land. It benefitsandaddsvaluetoagriculturalproducts produced by the community. Nevertheless, if that development may positively or negatively impact the community's environment caused by rapid changes may damage the ecosystem or environment from the study of government supervision in village development (Terdchai,2009) ${ }^{17}$ it is found that the critical factors in local tourism development that the government should pay attention are consist of 3 essential parts, which are:

1. Manage the base of resources, capital, society, culture, identity, and wisdom.

2. Balance the marketing management by focusing on quality tourists

3. Create management based on community participation (King Prajadhipok's Institute, 2009)
For the Pujon Kidul tourism village, development has obstacles in development supported by the government. The village should receive the necessary infrastructure support. It will increase the better quality of life of individuals and the community. The government should support agriculture by increasing the value of agricultural products, which will lead to job creation and increased income for people in the community. Regarding improving the quality of people's lives in the community, the most important thing is that they should be given priority. It is natural resources of communities or local areas due to the village's development into a tourism village is a rapid change that may cause the ecosystem or natural resources of the community to deteriorate (Panyapiwat, 2013). Development must consider the community's ecology because the community ecosystem is the surrounding nature of people in the community. The tourist village Pujon Kidul is a tourist village that is in direct contact with nature. Must consider the environment, both waste, and pollution, to maintain and use resources to maximize benefits to increase the community's value and business expansion. Therefore good governance should have good management regarding management, namely the use of resources appropriately and efficiently.

17 Terdchai. (2009). Organization's role in sustainable tourism development. Cabinet and Royal Gazette Publishing office. 
Important factors influencing the development of the tourist village of Pujon Kidul

\section{Human Capital}

For human resource development in the village, Pujon Kidul has trained experts from nearby villages and people's training within the village itself. The training is for people in the community to have skills in their careers and generate income for themselves and their families, especially the women in the community, which is considered to increase the women's skills in the community to have a career and increasing employment for the community. However, from the survey and analysis of Pujon Kidul village in this study, there is an obstacle in human development of the community which is education, because most people have average knowledge of primary and lower secondary levels, which is considered as an obstacle to development, especially for the communication.

\section{Local Participation}

Community participation is that community leaders play an essential role in determining the direction of development. The participation of people in the community is only one part of supporting the direction. The primary duty of determining direction is a community leader. It is in line with the participation theory that Garrod (2001) mentioned in people's participation in the community. It allows the community to participate in determining the direction of development of the community. It is to benefit from both direct and indirect development. From the researcher, people's participation in the community is that every member of the community is involved and has the right to establish development directions. Not just part of the support, but everyone can join in defining democratic principles in which the development will allow the community to develop appropriately. Participation is considered the heart of community development.

\section{Financial management}

The government funds the initial investment. Moreover, later, the money raised by the people in the village will be used to invest in the highest value by using it to develop the village into a tourist village. The interview from Head of Pujon Kidul village (Mr. Udi) related to Krisda (2019) theory is consistent in prioritizing the management of the acquisition and use of funds investment decisions. Meanwhile, village leaders have financial decisions. Both in investment in assets and working capital management, which is essential for the community's financial management and business expansion to create the business's highest value from the researcher's perspective in financial management, the government should support community investment. To be used as a reserve fund or to be used in the future, the government should inspect 
the allocation of the budget of the village leaders to ensure transparency in operations and ensure that the money received is used to maximize efficiency.

\section{Managerial Skills}

The leader has planning, organization, and leading in the construction of rural tourism villages. The head of the village has applied technical skills, which are planning skills and develop others. The management plans to develop from the village into a tourism village and use the skills to teach and develop people to be knowledgeable. Skills and abilities by sending personnel to increase skills with nearby villages and social skills, the head of the village use their skills to inspire and motivate others. By selfdevelopment in work or being a good role model in work and thinking skills, the head of the village has used strategic management by seeing the prominent point in the community. The natural resources that are availably recognizing the potential and the abundance of agriculture that will develop into business and profitability maximize resource utilization. All of this shows that the leader uses three skills in village management. According to Sdcenter (2011), interviews and theories are consistent; executives must perform all-around management tasks, including planning, organization, orientation, and control. For successful management, the executive should have good management skills based on at least three things: technical skills, human skills, and thinking skills.

From the problems discussed above, the researchers think that Human capital problems can indicate social inequality because most people do not have access to all these essential benefits, such as needy people who cannot receive an equal education. The other problem, the researchers in this research think, may cause long-term problems later, such as unemployment, problems of social inequality, etc. Therefore, the government should have a policy to promote education from primary education in kindergarten to high school and develop people's potential in the village. It may have the policy to promote the development of people in the village by providing training to increase language skills or have various experts create jobs for people in the village. It will make Pujon Kidul tourist village have the potential to develop into a full tourist village. It is in line with Backer and Kusluvan et al. (1962), a human capital theory that focuses on education in developing potential knowledge of personnel in the community.

Governance development of the Pujon Kidul's tourism village from the above information, the conclusion is that Pujon Kidul Tourism Village Development Potential the analysis of 4 essential factors affecting tourism village development. Four factors can be analyzed:

The factors that demonstrate the potential to Pujon Kidul tourism village development's governance are the local 
participation and managerial skills. The factor of local participation demonstrates enthusiasm, unity, and cooperation of communities in developing their villages to be a tourism village by having a leader, which is the head of the village, determines the direction and decisions. The people in the community have a duty to follow. The managerial skills factor that the head of the village can be a leader in developing the village into a tourism village. The head of the village sees the community resources' value and ways to increase community resources, including agricultural, livestock, and human resources, by creating networks between communities to exchange knowledge and develop potential.

\section{Conclusion}

The above information can summarize the supervision of the Pujon Kidul tourism village. Relevant agencies should support supervision. That is the government sector and, most importantly, the use of resources in the community to maximize benefits to increase the community's value and business expansion.

From the essential factors in the development of Pujon Kidul village can be summarized as follows:

Human Capital, the majority of the personnel problem in Pujon Kidul village, is education. From the interviews of the leader of Pujon Kidul village, it is found that the majority of the personnel have average education from primary to lower secondary education. Resulting in the ability to communicate with tourists, which are in line with the human capital theory of Backer and Kusluvan et al. (1962). That focuses on education in the development of potential knowledge of personnel in the community.

Local participation, consistent with the participation theory in some parts, the community can determine the direction of community development and benefit from both direct and indirect development. Meanwhile, from the interviews with the community leaders, it was found out that the essential role in determining direction is the leader of the village. Community participation is, therefore, only as support.

Financial Management, from the interviews and theories (Udi,2020) and (Krisda,2019), is essential to focus on investment decisions. In both working capital and investment in assets, which is essential for managing and expanding the community business. Because the village's financial condition began from people's fundraising, they have to decide carefully before investing in hedging.

Managerial Skills, administrators operate according to the theory of thinking in looking at the community. Moreover, social skills in developing personnel in the community to have the knowledge and all-around skills include sending personnel for training to increase the community's potential and create more value-added products. 
The factors that demonstrate the potential to the governance of Pujon Kidul tourism village development have two factors. The factors of local participation and the managerial skills of this village are research that supports the research facts: Community Based Tourism: A case study of Baan Rong Fong, Rong Fong Sub-District, Mueang Phrae District, Phrae Province. From the research, we can study the potential of Ban Rong Fong in developing to be a tourist village by community-based. A section that is consistent and supports the facts is community involvement in which everyone helps to implement the practice in village development and village leadership skills in increasing resource value and building networks with nearby communities to support and share knowledge.

The factors that difficulty to the governance of Pujon Kidul tourism village development is the humancapital and financial management. The human capital factor, related to the research called PENINGKATAN KAPASITAS PENGELOLAAN DESA WISATA KAFE SAWAH PUJON KIDUL, which is a demonstration of the educational problems of personnel in developing educational potential. As for financial management, the community has raised funds to develop the village. This fact is based on research that enables factors in Community Development Achievement Based on the Sufficiency Economy Philosophy of Ban Namsab Community, Wangnamkheo Sub-district,
Wangnamkheo District, Nakhonratchasima Province. Some studies have issues that are consistent with the research and conflict as follows. The issues consistent with the facts are that the community has raised funds to be used as a budget for village development. An internal factor that promotes the success of the community development, but at the same time, an external factor, a village did not receive a budget from the government to support the community.

\section{Suggestion}

The promotion of tourism in each location is like providing tourism information in exciting places. It should be promoted through various online channels because the Pujon Kidul village does not receive sufficient advertising support. So it may result In tourism that may receive only one place of interest, which tourists do not distribute to other places. The head of the village can take the results from research to develop villages to have more potential, a model for other village development.

\section{References}

Karim, A. (2008). Kapitalisasi Pariwisata dan Marginalisasi Masyarakat Lokal di Lombok. Yogyakarta: Genta Press.

Essays, UK. (2018). Role of Government in

Tourism. Retrieved 15 February 2020, from https://www.ukessays.com/ essays/tourism/role-of-governmentin-tourism-tourism- essay.php. 
Komunitas Averroes. (2017). Pujon Kidul Tourism Village. Retrieved 6 January 2020, from https:// $\mathrm{w}$ w w $\mathrm{k}$ o m pas i a $\mathrm{n}$. c o m / avecom/5aObb20d2599ec04e617da73/ kisah-di-balik-suksesnya-desa-wisatapujon-kidul?page $=$ all

Sid Israel. (2018). Development. Retrieved 7 January 2020, from https://www.sidisrael.org/en/Development-Issues / What-is-Development.

Tamayaocsu. (2014). What is governance? Retrieved 7 January 2020, from https://tamayaosbc.wordpress. com / $2014 / 08 / 21 / \mathrm{wh}$ at - is governance/.

CBT Youth Club. (n.d.). Community - Based Tourism, from https://cbtyouth. wordpress.com/cbt-youth/cbt/

Becker, G. S. (1962). Investment in human capital: A theoretical analysis. Journal of Political Economy, 70, 9-49.

Garrod, Brain. (2001). Local Participation in the Planning and Management of Eco-tourism: A Revised Model Approach Bristol. England: the University of the West of England.

Krisda Sektrakul. (2019). หลักการบริหารการเ งินฉบับย่อสาหรับการลงทุนในบริษัทจดทะเ บียน. Retrieved 13 January 2020, from https://www.set.or.th/set/ financialplanning/knowledgedetail. do? contentId=576\&type $=$ article .

Sdcenter. (2011). Good managerial skills. Retrieved 13 January 2020, from http://oknation.nationtv.tv/blog/ thaidbmag/2011/06/30/entry-1

Chai Phositita. (2007). Art and science of qualitative research. Nakornpathom: Institute for population and social research Mahidol university.

Terdchai. (2009). Organization's role in sustainable tourism development. Cabinet and Royal Gazette Publishing office.

Chutikan Kantha-oo. (2017). COMMUNITYBASED TOURISM: A CASE STUDY OF BAAN RONG FONG, RONG FONG SUB-DISTRICT, MUEANG PHRAE DISTRICT, PHRAE PROVINCE. The Degree of Master of Arts Program in Human and Social Development (interdisciplinary Program) Graduate School. Chulalongkorn University.

Anucha pimindnok, Pakkawan lunsomgrong.

(2015). Enable Factors in Community Development Achievement Based on the Sufficiency Economy Philosophy of Ban Namsab Community, Wangnamkheo

Sub-district, Wangnamkheo District, Nakhonratchasima Province.

Nakhonratchasima: Nakhonratchasima College.

Erlin Melani, Aang Afandi, Andi Kusuma Indrawan. (2019). Peningkatan Kapasitas Pengelolaan Desa Wisata Kafe Sawah Pujon Kidul. Jurnal PKM: Pengabdian kepada Masyarakat. 
LONGKUL, WONGPON, BURANA, PUTRI, SAFITRI, ROMADHON, Governance Development of... 134

Ali Roziqin, Adejaya MS, Khadir Ali. (2019). Siti Nurulwahida, Yana Syafrieyana, Oman Strengthening Local Economy Sukmana. (2020). Collaboration with through Tourism Village: Case Pentahelix Model in Developing Study in Dukuh Dalem, Sleman Kajoetangan Heritage Tourism City. PROCEEDINGS: IAPAAnnual in Malang City. Journal of Local Conference, 2018. Government Issues. 1-17. 